\title{
Holocene growth history of a reef complex on a cool-water carbonate margin: Easter Group of the Houtman Abrolhos, Eastern Indian Ocean
}

\author{
L.B. Collins ${ }^{\mathrm{a}}$, Z.R. Zhu ${ }^{\mathrm{a}}$, K.-H. Wyrwoll ${ }^{\mathrm{b}}$, B.G. Hatcher ${ }^{\mathrm{c}}$, P.E. Playford ${ }^{\mathrm{d}}$, A. Eisenhauer ${ }^{\mathrm{e}, 1}$, \\ J.H. Chen ${ }^{\mathrm{e}}$, G.J. Wasserburg ${ }^{\mathrm{e}}$ and G. Bonani ${ }^{\mathrm{f}}$ \\ ${ }^{a}$ School of Applied Geology, Curtin University of Technology, Perth, WA 6102, Australia \\ ${ }^{b}$ University of Western Australia, Nedlands, WA 6009, Australia \\ ${ }^{\mathrm{c}}$ Department of Oceanography, Dalhousie University, Halifax, N.S. B3H 4JI, Canada \\ ${ }^{\mathrm{d} G e o l o g i c a l ~ S u r v e y ~ o f ~ W e s t e r n ~ A u s t r a l i a, ~ E a s t ~ P e r t h, ~ W A ~ 6004, ~ A u s t r a l i a ~}$ \\ ${ }^{\mathrm{e}}$ Division of Geological and Planetary Sciences, California Institute of Technology, Pasadena, CA 91125, USA \\ ${ }^{\mathrm{f}}$ Institut für Mittelenergiephysik der ETH Zürich, ETH-Hoenggerberg, CH-8093 Zurich, Switzerland
}

(Received March 5, 1993; revision accepted August 18, 1993)

\begin{abstract}
Collins, L.B., Zhu, Z.R., Wyrwoll, K.-H., Hatcher, B.G., Playford, P.E., Eisenhauer, A., Chen, J.H., Wasserburg, G.J. and Bonani, G., 1993. Holocene growth history of a reef complex on a cool-water carbonate margin: Easter Group of the Houtman Abrolhos, Eastern Indian Ocean. Mar. Geol., 115: 29-46.
\end{abstract}

The Houtman Abrolhos reefs, situated on the western continental margin of Australia, occupy a transitional position between cool-water shelf carbonate sediments to the south and more tropical environments to the north. Their existence at the outer limits of the geographical range for coral reef growth is a result of the warm, poleward-flowing Leeuwin Current. Though the modern reefs differ ecologically from tropical reefs, their geological characteristics have been little known until recently. Each of the three island groups in the Abrolhos consists of a central platform of Last Interglacial reefs, about which windward and leeward Holocene reefs have developed asymmetrically. In the Easter Group the subtidal windward reef in the west is ca. $10 \mathrm{~m}$ thick and is backed by a leeward-prograding, lagoon sand sheet which is $0-3 \mathrm{~m}$ thick. The emergent parts of the leeward reefs in the east consist of an upward-shallowing sequence comprising reef facies, peritidal rudstone facies, and coral rubble storm ridges. This is underlain by over $26 \mathrm{~m}$ of Holocene reef facies. Coring and dating of the Holocene reefs (using both U/Th TIMS and ${ }^{14} \mathrm{C}$ methods) in the Easter Group has shown significantly different lithofacies in the windward and leeward reefs, and has allowed reconstruction of Holocene reef growth and sea-level history. Coralline algal bindstones and interbedded coral framestone facies characterise the relatively slow-growing windward Holocene reefs, whereas the fastgrowing leeward reefs consist of coral framestone facies which are dominated by Acropora. The leeward reefs commenced growth about $10,000 \mathrm{U} / \mathrm{Th}$ years ago and the Morley reef grew to $0.3 \mathrm{~m}$ above present sea level by $6400 \mathrm{U} / \mathrm{Th}$ years B.P., recording a relative high sea-level event. This generated Holocene constructional topography characterised by "blue-hole" terrain. Windward Holocene reef growth commenced after 8200 U/Th years B.P. following erosion of the windward part of the Last Interglacial platform. High wave energy and competition with macroalgae limited coral growth, and the coralline algal-dominated windward reefs grew more slowly to sea level. The Holocene sea-level record provided by dates from the 26 $\mathrm{m}$ core of the Morley reef (a "keep-up" reef) is the first such record from the western continental margin of Australia.

\section{Introduction}

The southern and western continental margins of Australia are characterised by carbonate sedi-

${ }^{1}$ Present address: Institut fur Umweltphysic der Universität Heidelberg, Germany mentation which regionally shows a latitudinal variation in skeletal grain assemblages. On the south and southwest margins (latitudes $30^{\circ}$ to $\left.44^{\circ} \mathrm{S}\right)$ carbonate sediments are composed of a bryozoan-coralline algal assemblage as part of a cool-water carbonate province extending across southern Australia (Collins, 1988; James and von 
der Borch, 1991). The tropical coral-green algal assemblage occurs at Shark Bay, on the western margin at latitude $26^{\circ} \mathrm{S}$ (Logan et al., 1970). Late Quaternary coral reefs have developed at latitudes $28.3^{\circ}$ to $29^{\circ} \mathrm{S}$ at the Houtman Abrolhos carbonate platforms, which have otherwise been characterised by cool-water carbonates since the Eocene. The Houtman Abrolhos are a chain of shelfmargin coral reefs which form the southernmost reef complex of the Indian Ocean. Their latitudinal position places them at the outer margin of the generally accepted geographical range for significant coral reef development, in a region dominated by more temperate communities and cool-water shelf carbonates. Little was previously known of the Quaternary history of these reefs, and whether reefs located in such transitional environments differ from their tropical counterparts.

Ecological researchers in the Abrolhos described these reefs as "high latitude reefs" (Hatcher, 1985, 1991; Crossland, 1988) and demonstrated significant differences in community structure and function compared to tropical reefs, with intense competition between temperate marcoalgal and tropical coral communities (Wilson and Marsh 1979; Hatcher 1991). The initial geomorphological and geological research on the Abrolhos reefs was by Teichert (1947) and Fairbridge (1948). In the last decade, further work has added to our knowledge of the geology and geological development of the reef complex (France 1985; Veeh and France 1988; Collins et al., 1991). However, these studies were entirely based on surface exposures and sediments. Knowledge of Holocene reef growth was therefore very limited. Holocene reefs were thought to have developed only as a veneer over the karst erosional surfaces of the Late Pleistocene reef complexes (Fairbridge, 1948; France, 1985) and the Holocene was believed to have been an unfavorable time for coral reef growth (France, 1985; Crossland, 1981; Hatcher, 1991).

One of the questions for the geological research was whether the present-day coral-macroalgal system had prevailed throughout the Holocene, thereby limiting reef growth to thin veneers over a pre-Holocene surface, or whether Holocene reef growth had been as vigorous as in tropical reefs. As part of a wider geological study of the
Abrolhos, cores were obtained in the Holocene reefs. In this paper we present results of the Holocene stratigraphy and chronology, document the facies characteristics of the Holocene reefs, and describe their growth history and controls on development.

\section{Methods}

Geological mapping and sampling of the emergent parts of the Abrolhos reefs (Fig. 1) were conducted on the three island groups (Pelsaert, Easter and Wallabi Groups), during field investigations to establish the regional stratigraphy. A coring program was carried out on the reefs in the Easter Group in order to investigate the subsurface stratigraphy and to obtain samples for radiometric dating. A total of 6 cores from the central platform (Rat Island and Roma Island), windward reef (Disappearing Island and Sandy Island) and leeward reef (Morley Island and Suomi Island) were obtained (Fig. 2), and penetration ranged from 5 $\mathrm{m}$ to $26 \mathrm{~m}$. Corals from the Morley, Suomi, Rat and Disappearing Island cores were dated and the $26 \mathrm{~m}$ Morley core was dated radiometrically at ca. $2 \mathrm{~m}$ intervals. The Morley core lacks vertical facies differentiation, but is dominated by fast growing

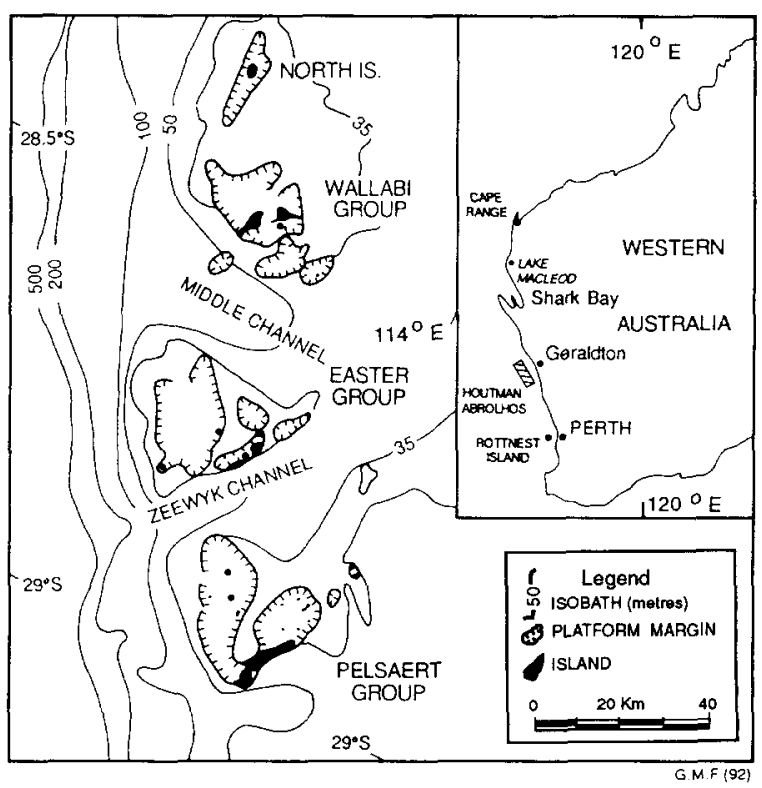

Fig. 1. Location map of Houtman Abrolhos Islands. 


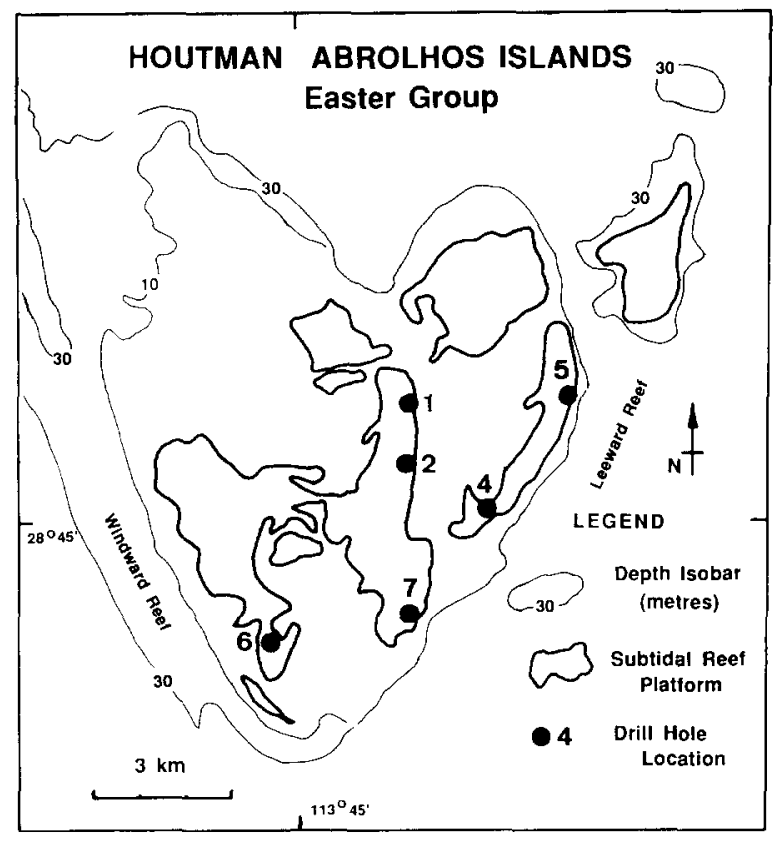

Fig. 2. Morphology of the Easter Group, including island and core locations. Cores were taken in the Windward Reef $(6=$ Disappearing Island; $7=$ Sandy Island $)$; Central Platform $(I=$ Rat Island; $2=$ Roma Island) and Leeward Reef ( $4=$ Morley Island, $5=$ Suomi Island).

Acropora spp. Samples selected for dating were prepared so as to remove any visible contamination, including encrustations, borings and internal sediments and cements. The mineralogy of the samples was examined by $\mathrm{X}$-ray diffraction, and the petrology was investigated using thin sections (Eisenhauer et al., 1993; Zhu et al., 1993). Corals from cores were dated by thermal ionization mass spectrometry (TIMS) techniques at Caltech. The analytical procedures are similar to those described by Chen et al. (1986) and Edwards et al. (1987). Thirteen corals dated by the TIMS technique were also dated by the accelerated mass spectrometer (AMS) ${ }^{14} \mathrm{C}$ method, in order to provide comparative data. The chemical preparation of ${ }^{14} \mathrm{C}$ samples was performed at the ${ }^{14} \mathrm{C}$ laboratory of the Institut für Umweltphysik at Heidelberg University, Germany using methods described by Kromer et al. (1986) and Wolfli (1987). The age determination was undertaken at the Institut für Mittelenergiephysik at the ETH-Zürich, Switzerland, using an AMS accelerator.

A full discussion of X-ray diffraction data, sample preparation, procedures for $\mathrm{U} / \mathrm{Th}$ and ${ }^{14} \mathrm{C}$ measurements and date assessments is given in Eisenhauer et al. (1993, tables 1 and 3). For the purposes of U/Th (TIMS) dating, $\delta^{234} \mathrm{U}(\mathrm{T})$ values (initial ${ }^{234} \mathrm{U} /{ }^{238} \mathrm{U}$ activity ratio) of the corals dated are consistent with closed system behaviour, indicating a lack of diagenetic alteration. On average, ${ }^{14} \mathrm{C}$ ages were found to be about 1000 years younger than their corresponding U/Th ages, confirming previous results by Bard et al. (1990, 1993) and Edwards et al. (1993).

\section{Geological setting and physical environment}

The Abrolhos reef complex is located $70 \mathrm{~km}$ from the Western Australian coast (Fig. 1). The emergent parts of the reef complex consist of more than 100 islands which occur in three groups. The central Easter Group is separated by channels of ca. $40 \mathrm{~m}$ depth from the northern Wallabi Group and the southern Pelsaert Group (Fig. 1). The three island groups differ significantly in their overall geomorphological expression. However, a windward reef, leeward reef, and lagoon with a central platform are distinguishable in each group of reefs. The preliminary dating results show that the central platforms are Last Interglacial in age, and Holocene reef facies occur within the windward (western) and leeward (eastern) reefs (Veeh and France, 1988; Collins et al., 1993). The islands of the Abrolhos generally rise some 3-5 $\mathrm{m}$ above present sea level. Extensive "blue-hole" terrains occur at the eastern parts of the island groups, but are absent from the western and central parts.

Geologically, the Abrolhos reef complexes are at the northern end of the Perth Basin which has a narrow, open carbonate shelf and lies along the quiescent rifted margin of southwest Australia (Veevers, 1974; Collins, 1988). During the Tertiary, the Abrolhos region developed a suite of coolwater carbonate sediments, dominated by bryozoan-mollusc-echinoid skeletal calcarenites and calcilutites and lacking reef-building corals (Hawkins, 1969). The deepest coral was found at $-67 \mathrm{~m}$ in cuttings of a well in the Pelsaert Group (Hawkins, 1969), which may indicate the thickness of the Abrolhos coral reefs. The age of this material is, however, unknown. Reefs were actively formed 
during the Last Interglacial and remnants of these reefs form the contemporary central platforms, where drilling in the Easter Group penetrated 15 $m$ of reef facies without reaching an older unit. The Last Interglacial reefs consist predominantly of branching and head coral framestones. The upper part of these reefs is composed of an upwardshallowing sequence, consisting of coral framestone and/or coralline algal bindstone, overlain by medium to coarse grained, shelly skeletal grainstone to rudstone. These are dense and calcretized limestones. The Holocene reefs in the Pelsaert and Easter Groups consist of a crescentshaped windward reef backed by a lagoon sand sheet, and a leeward reef complex of reticulate reefs and lagoon patch reefs. In the Wallabi Group the windward reef and associated lagoon are less well-developed. Sediments on the shelf surrounding the Abrolhos platforms consist of a suite of cool-water carbonates composed of bryozoans and calcareous red algae with minor molluscs, foraminifers and echinoids (France, 1985).

The Abrolhos region has a Mediterranean climate, with hot, dry summers and cool, wet winters. It is in a microtidal environment. Dominant winds are from the southwest to southeast. Storms are significant and summer tropical cyclones (hurricanes) have an average frequency of once every 3 years (Steedman et al., 1977). Up to $90 \%$ of cyclones approach from the northwest. Persistent swell waves with a mean height of $1.2 \mathrm{~m}$ impinge on the Abrolhos throughout the year, approaching from the south and west $78 \%$ of the time (Steedman et al., 1977). Wave impact energy is strongest on the southwesterly reef margins, forming the high energy, windward regime of the platforms, whereas significant refracted swell waves and wind waves impinge on southeast margins, forming medium energy, leeward environments. Mean annual sea-surface temperatures at the Abrolhos normally range from $26^{\circ} \mathrm{C}$ in summer to $18^{\circ} \mathrm{C}$ in winter (Wilson and Marsh, 1979). They fall below $20^{\circ} \mathrm{C}$ for up to $30 \%$ of the time (France, 1985) and may fall below $17^{\circ}-18^{\circ} \mathrm{C}$ for several days at a time in areas of restricted circulation (Wilson and Marsh, 1979; Hatcher et al., 1987). Conditions are thus often near the limits for the growth of reef-building coral (Crossland, 1984). A southerly flowing, warm-water current, the Leeuwin Current, flows along the continental margin to the west of the reef complex (Cresswell and Golding, 1980; Pearce, 1991). The current is believed to have come into existence during the Early to Middle Pleistocene, as evidenced by molluscan and coral assemblages in the regional geological record (Kendrick et al., 1991).

\section{Present day reefs}

Biogeographically, the Abrolhos region is located in the Western Coast Overlap Zone (Morgan and Wells, 1991) between the Northern Australian Tropical and Southern Australian Warm Temperate Provinces. This transition zone is characterised by the gradual replacement of a tropical fauna in the north by a predominantly temperate fauna in the south (Morgan and Wells, 1991). Coral faunal communities at the Abrolhos are highly diverse. 184 species and 42 genera of corals are recorded (Veron and Marsh, 1988). The number of genera is much higher than other "high latitude" coral reefs (e.g. Veron 1974 for the Solitary Islands; Dana 1971 for Kure Atoll; Garrett et al., 1971 for Bermuda Reefs). The $\mathrm{CaCO}_{3}$ production rate of the Abrolhos coral reefs is not significantly different from that of tropical reefs (Smith 1981; Kinsey 1985). Acropora, which is missing from or very rare on many "high latitude" reefs (Garrett et al., 1971; Smith 1981), is the dominant coral.

The windward section of the reef platforms generally lacks well developed coral communities, although solitary corals are common. Here there grows an assemblage of macroalgae of temperate and tropical affinities including extensive stands of the kelp Ecklonia radiata (Wilson and Marsh, 1979; Hatcher et al., 1987). The leeward section of the reefs and the lagoons support rich coral communities with high community production and calcification rates (Wilson and Marsh, 1979; Smith, 1981; Hatcher, 1991). The most dense living cover occurs on leeward reef-front slopes, around the upper edges of "blue-holes", and on lagoon patch reefs. In all of these areas the diversity of corals is relatively low, dominated by tabular and staghorn Acropora, but coral growth can be extremely luxu- 
riant (Wilson and Marsh, 1979). Dead fragments of corals constitute the main components of the bioclastic material which overlies the leeward reef flats, forming bedded, intertidal rudstones and, on the low islands, storm shingle ridges.

A high diversity of corals occurs at the bottom of leeward reef fronts and channel slopes at depths greater than $20 \mathrm{~m}$, where massive, encrusting, foliose and branching corals exist (Wilson and Marsh, 1979). High coral diversity is also observed on overhangs and hard substrate exposures on the sides of lagoons and "blue-holes". Submerged reef platforms and intertidal reef flats generally have very sparse coral growth although diversity can be relatively high. These environments are dominated by brown algal genera such as (particularly) Cystophyllum, Turbinaria, Caulocystis, Sargassum and Hormophysa (Wilson and Marsh, 1979).

\section{Lithostratigraphy}

Holocene lithofacies are present both in outcrop and core in the Easter Group. An understanding of the evolution of the reef system is provided by the depositional environments and sequences represented. The lithostratigraphic sequence of outcrops of the Holocene reefs is summarised in Fig. 3. This sequence represents the lithology of the emergent parts of the leeward reefs, and reefs in the lagoon, while the windward reefs are subtidal with the exception of a few small sand cays (e.g. Disappearing Island). Thin $(0-3 \mathrm{~m})$ sand sheets mantle the windward side of reef platforms, and are present in lagoonal areas of the Easter Group (Fig. 4A). The Holocene sequence consists of five sedimentary facies types: coral framestone facies; algal bindstone facies; well-bedded coral rudstone facies; unlithified coral rudstone facies; and skeletal grainstone facies (Figs. 4-6). The first four of these facies comprise an upward-shallowing sequence, whilst the fifth comprises lagoon sand sheets.

\section{Coral framestone facies}

This facies is over $26 \mathrm{~m}$ thick and is formed predominantly by staghorn branching corals (Acropora spp.) which are usually in growth position (Figs. 4C and 6C). Tabular Acropora species and encrustation of corals by coralline algae and foraminifers increase in the upper parts of the section in the leeward reefs. The framework is normally very porous and the pores are partially filled by skeletal matrix and marine carbonate cements. The matrix consists of mollusc shell fragments, coralline algae, foraminifers and bryozoan fragments which are cemented by $\mathrm{Mg}$-calcite

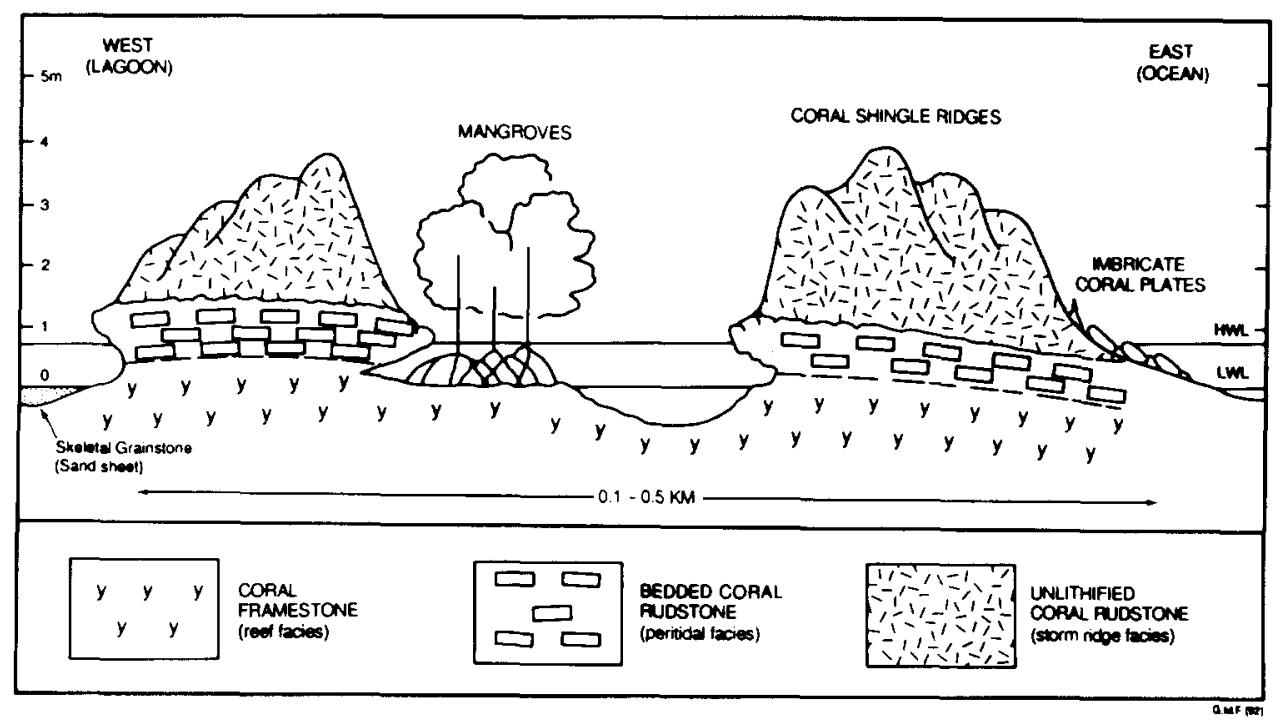

Fig. 3. Morphostratigraphy of Holocene islands in the leeward reefs. Emergent coral framestone is overlain by well lithified, bedded coral rudstone. Island surfaces consist of storm ridges composed of coral rubble. 

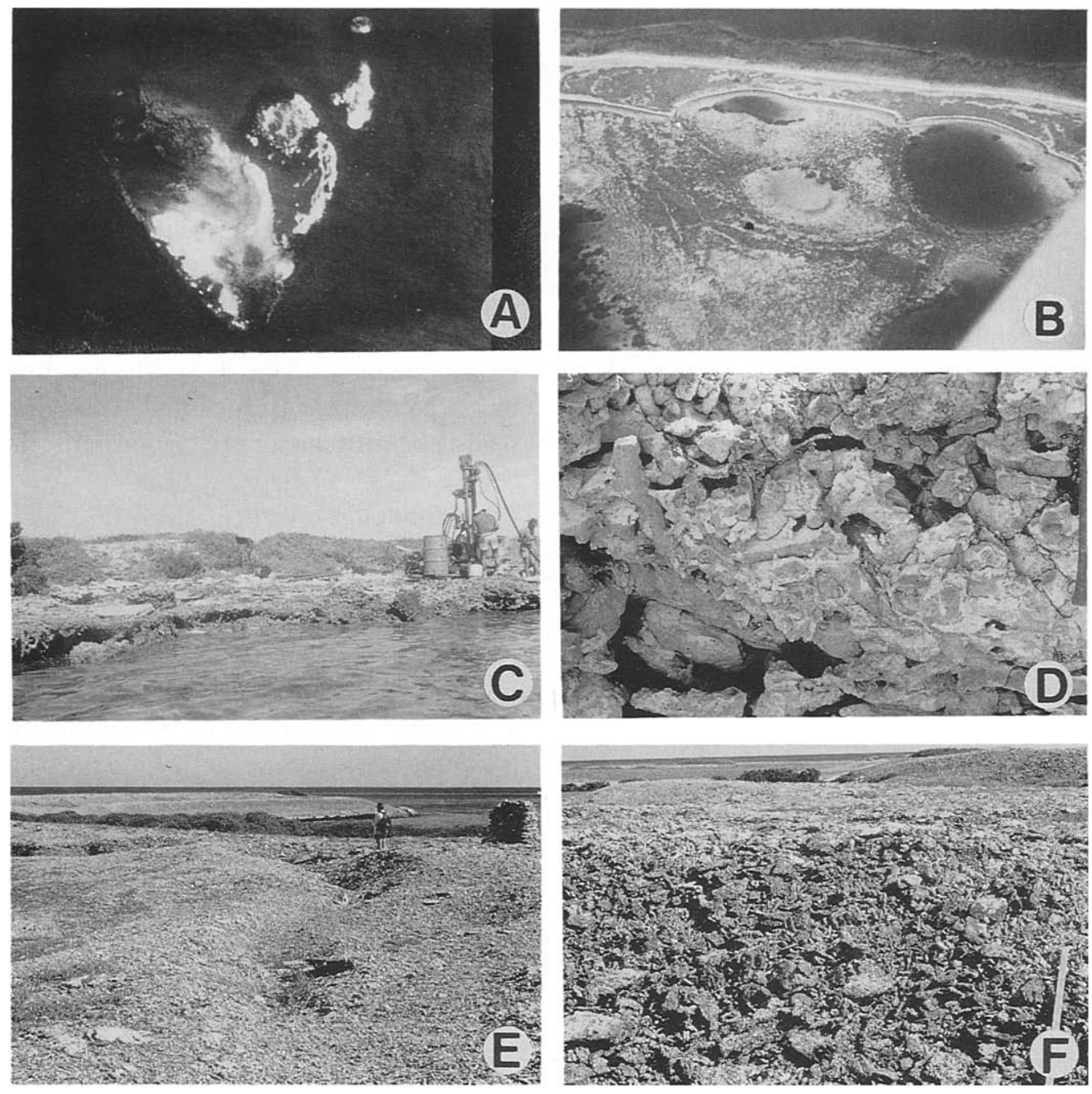

Fig. 4. Morphology and lithostratigraphy of the Easter Group. (A) Landsat image of Easter Group showing (from lower left): windward reefs (indicated by line of breaking waves); platform sand sheet (white); central platform; and leeward reefs. Platform width is $15 \mathrm{~km}$. (B) Aerial view of part of Suomi Island (north is to left; width of field of view is $0.5 \mathrm{~km}$ ). Leeward (eastern) reef margin is along top of photo. Island surface is composed of coral rubble storm ridges. "Blue-hole" adjacent to island is $100 \mathrm{~m}$ across. (C) Lagoon shore of Suomi Island at drillsite (core 4). Emergent coral framestone (foreground) is overlain by bedded coral rudstone and coral rubble storm ridges. (D) Close-up of bedded coral rudstone unit. Coral plates and rods are encrusted and cemented by coralline algae (white). Height of field is $25 \mathrm{~cm}$. (E) View of leeward island surface showing storm ridges composed of coral rubble, at Serventy Island. (F) Close-up of storm ridge showing unlithified rudstone fabric of coral plates and rods, Serventy Island

micrite and fibrous aragonite cements. Some parts of the framestone have rudstone fabric, expressed by preferentially oriented fragments of branching corals (Fig. 6D), but these coral fragments lack well defined stratification. Surface textures of the coral skeletons are relatively well preserved, indicating little transportation or abrasion. This fabric is believed to be an integral portion of the growing reef and probably results from small-scale collapse and compaction of porous reef. Framestone facies form a major part of the leeward reefs, patch reefs in lagoons, and some parts of the windward reefs. The $26.5 \mathrm{~m}$ core obtained from Morley Island and the $16.5 \mathrm{~m}$ core from Suomi Island in the leeward reefs are composed predominantly of framestone facies. In the windward reef the framestone facies 
occurs as thin units within bindstones and is normally modified by extensive boring and encrustation by molluscs, serpulids and coralline algae (Fig. 6B).

Coral framestone facies normally crops out in the leeward islands from 0.2 to $0.5 \mathrm{~m}$ above the present sea level and consists mainly of branching Acropora with distinctive growth features (Fig. 4C). These emergent framestones in island sequences represent the uppermost parts of the extensive Holocene leeward reefs intersected in cores. The framestones, which are usually overlain by coralline algal bindstones, a few to $20 \mathrm{~cm}$ thick, occur about $0.5 \mathrm{~m}$ above the uppermost growth of their modern analogues, indicating sea levels at least $0.5 \mathrm{~m}$ higher than at present when they formed. The emergent framestone facies is observed in leeward islands in all three reef groups and is particularly well preserved on the lagoon shores of these islands (Fig. 4C).

\section{Algal bindstone facies}

This facies is up to $9 \mathrm{~m}$ thick and consists predominantly of an encrusting assemblage of coralline algae, foraminifers and serpulids (Fig. 6A and $\mathrm{B}$ ). The lithofacies is predominant in windward reefs as revealed in cores from Disappearing Island and Sandy Island (Fig. 5, cores 1 and 2). The encrusting assemblage of coralline algae, foraminifers and serpulids is interbedded with thin intervals of coral framestone in which corals are heavily bored by serpulids and molluscs, and encrusted by algae and foraminifers. Compared with coral framestones in the leeward reefs, bindstones in the windward reefs have relatively fewer voids and less skeletal sediment infills and carbonate cements. The bindstones unconformably overlie preHolocene calcretized limestones at depths of between $4.5 \mathrm{~m}$ and $9 \mathrm{~m}$ in the windward reefs. They are rare in cores in the leeward reefs, but frequently form a thin $(<20 \mathrm{~cm})$ veneer overlying emergent coral framestone in the leeward islands.

\section{Well-bedded, coral rudstone facies}

This facies is $0.5-2 \mathrm{~m}$ thick, consists predominantly of branching and platy coral fragments and forms in the intertidal zone. The fragments of corals vary in size from 1 to $20 \mathrm{~cm}$ long and are frequently sub-horizontally oriented. The rudstone is widely distributed in the leeward islands (Fig. 4C). It overlies the peritidal to emergent coral framestone facies, forming reef platforms and islands. The rudstones contain less matrix than the underlying framestones, are porous but relatively well lithified and bound by encrusting coralline algae and marine cement (Fig. 4D). They differ from the underlying framestones in their distinct subhorizontal bedding and orientation of coral debris. Compared with the central platform limestones, the rudstone facies lacks calcrete and is relatively poorly lithified. The facies has not been observed in the windward reefs.

\section{Unlithified coral rudstone facies}

This facies is normally $1-2 \mathrm{~m}$ thick and consists of branching and platy coral fragments, commonly $5-20 \mathrm{~cm}$ in size. It forms linear rubble ridges on the leeward islands, usually overlying the well lithified, bedded coral rudstone (Fig. 4B and C). These subaerial ridges are composed of an open deposit of imbricate coral plates and rods, and voids lack sand-size sediment and cement (Fig. 4E and F). The ridges are believed to have been formed in the supratidal zone by the transportation and deposition of coral fragments during severe storms. Overturned, fan-shaped coral skeletons up to $50 \mathrm{~cm}$ across are sometimes found in swales between coral rubble ridges. The unconsolidated rudstone facies comprises most of the exposures of the emergent Holocene islands in the leeward reefs, and a few to over ten such ridges are usually present. At Serventy Island (Fig. 4E), a leeward island in the Easter Group, a sequence of eleven major ridges is developed as a $200 \mathrm{~m}$ wide, eastward- and leeward-prograding system.

\section{Skeletal grainstone facies}

This facies is composed of unconsolidated skeletal sand, which comprises thin (0-3 m) lagoon sand sheets. Compositional and size analyses show that corals and coralline algae are volumetrically most important, with minor molluscs, foraminifers, 


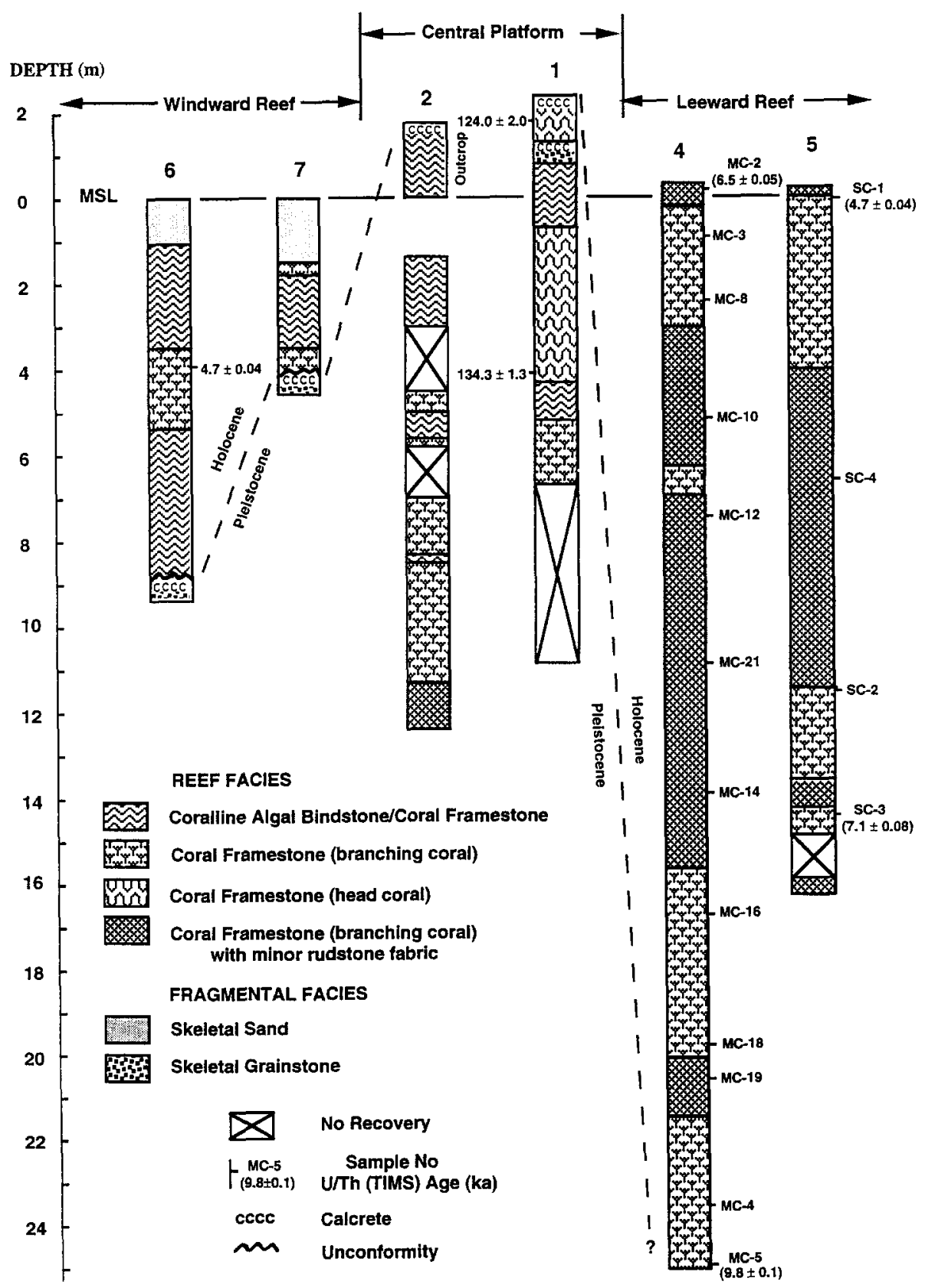

Fig. 5. Stratigraphy of Easter Platform. Windward and leeward reefs are Holocene; central platform consists of Last Interglacial reefs. For core locations see Fig. 2. Details of dated core samples (MC-1 etc.) are given in Table I.

bryozoans and echinoids. The size of skeletal grains varies from medium- to coarse-sand, and from fine sand to silt in deep lagoonal areas. Much of the sediment is generated by reef-crest communities of corals and coralline algae and is swept lagoonwards by wave- and wind-generated currents. The molluscan and foraminiferal debris is mainly generated within the lagoons. The skeletal grainstone facies occurs as the sediments of sand cays in the windward reefs, e.g. Disappearing Island, and laterally extensive sandsheets in lagoons (Fig. 4A). The thickness ranges from a few centimeters to up 
to $3 \mathrm{~m}$. In contrast to sediments on the shelf surrounding the platforms, which is coralline algal-bryozoan-dominated and is distinctly coolwater carbonate, platform sand sheets, consisting of corals and coralline algae, are more tropical in character, but lack green algae and non-skeletal grains.

From the lithofacies present in both outcrop and core, it can be seen that the windward and leeward reefs have contrasting thickness and lithofacies. The windward reef grew on the waveexposed margin of the Last Interglacial platform and reef thickness is less that $9 \mathrm{~m}$, whereas the leeward reef colonised substrates separate from, and on the leeward side of the platform, and thickness is in excess of $26 \mathrm{~m}$. While the windward reef is composed of an assemblage of coralline algae, serpulids and corals, the leeward reef consists predominantly of platy and branching corals (Figs. 5 and 6). The facies sequence in the leeward reefs indicates that when the reef grew to sea level it was progressively overlain by peritidal and subaerial facies, which now comprise the emergent islands of the leeward reefs.

\section{Age structure and accumulation rates}

The age structure of the Abrolhos reefs was poorly known until recently. Although as early as in the 1940's, Teichert (1947) had suggested that the limestones of the leeward reefs would be younger than those of the central platforms, no definite ages were determined. When constructing his global curve for sea-level variations in the Holocene, Fairbridge (1961) treated all the Abrolhos reef platforms as Holocene in age. Veeh and France (1988) reported two dates of corals determined by the $U$-series alpha-counting method. The corals were from the central platform and the leeward emergent coral fringe in the Pelsaert Group, and they have Last Interglacial and Holocene ages, respectively. It was believed that the Last Interglacial unit is widespread and dominates much of the geomorphology of the island groups (France, 1985). A regional dating program has shown that the central platforms of the Abrolhos consist of Last Interglacial coral reefs, whereas windward and leeward reefs are Holocene in age (Collins et al., 1993).

The U-series and ${ }^{14} \mathrm{C}$ ages of corals from cores of the Easter Group are summarised in Table 1. Detailed assessments of the ages are also described in Eisenhauer et al. (1993). These results have shown that the Holocene reefs are much better developed than previously thought. They are at least $9 \mathrm{~m}$ thick in the windward reef and over 26 $\mathrm{m}$ thick in the leeward reef. The dating results clearly demonstrate the growth characteristics of the Holocene reefs. The age and depth data of two cores from the leeward reefs (Morley and Soumi Islands; cores 4 and 5 respectively) have been used to demonstrate the growth characteristics of the leeward reefs (Fig. 7). Gradients of the regression lines obtained by least square analysis represent growth rates of the reefs. The growth trend and the corresponding vertical accretion rates are shown in Table 1 and Fig. 7. The following discussion is based on the U/Th time scale because these ages equate to calender years. The ${ }^{14} \mathrm{C}$ data are given for comparative purposes. It is apparent that the vertical accretion rates of the reefs vary both in time and space. The Morley reef, which probably grew as a lagoon patch reef, has the highest growth rates, with an overall average of $7.7 \mathrm{~m} / \mathrm{kyr}$ (with a correlation coefficient $R=0.97$ ) during the dated interval. The accretion rates of the Suomi core, taken from near the leeward reef crest, are relatively lower, with an average of $6.0 \mathrm{~m} / \mathrm{kyr}(R=$ 0.99 ). At present the chronological data are not sufficient to calculate the growth rate of the windward Holocene reefs. However, it appears that the windward reef reached present sea level later than the leeward reef. This is shown by the fact that the windward reef in the Disappearing Island core was still $3.9 \mathrm{~m}$ below present sea level at $4.7 \mathrm{kyr}$ B.P. (Fig. 4; Collins et al., 1993). The data also suggest that the growth rate of the windward reefs, dominated by coralline algal bindstones, is lower than that of the leeward reefs, composed of fastgrowing, branching corals.

Reef growth in the Morley core was in two stages. From a depth of $25 \mathrm{~m}$ to $5 \mathrm{~m}$ below present sea level, reef growth was very fast, with an overall vertical accretion rate of $10.2 \mathrm{~m} / \mathrm{kyr}$ by $\mathrm{U} / \mathrm{Th}$ age determination ( $R=0.99$; line 2 in Fig. 7). At about 

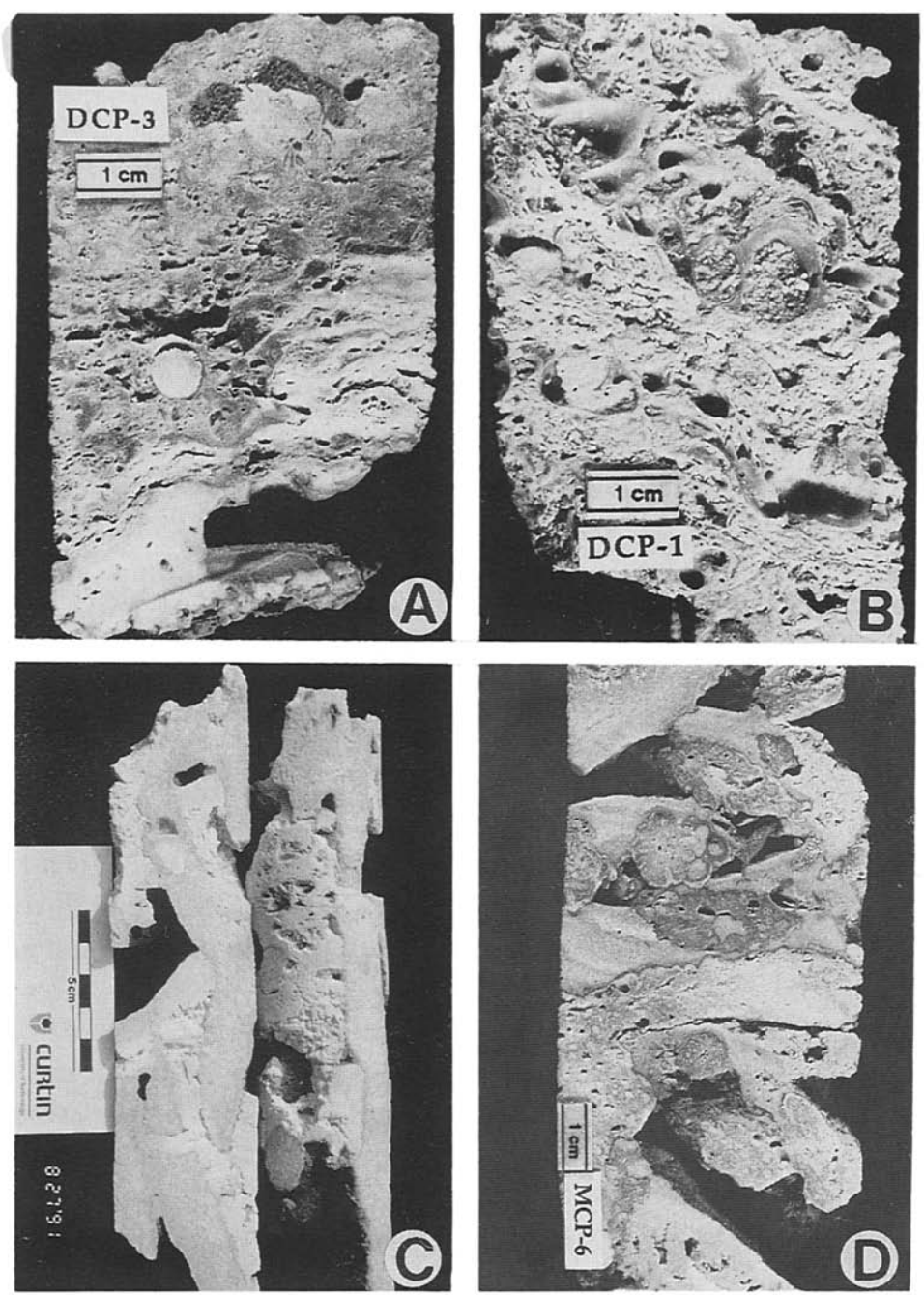

Fig. 6. Core photographs showing lithofacies of Holocene reefs. (A) Algal bindstone from windward reef. Note coralline algae (white), serpulids and corals are present in a mixed assemblage. (B) Algal bindstone with interbedded coral framestone from windward reef. Corals are present but never dominant in this lithofacies. (C) Coral framestone from the leeward reef. Branching Acropora is partly bound by a marine cement consisting of $\mathrm{Mg}$ calcite micrite and aragonite. (D) Rudstone fabric within coral framestone from the leeward reef. Note the sub-horizontal orientation of coral fragments.

$8000 \mathrm{U} / \mathrm{Th}$ yrs B.P., when sea level was about 5 $\mathrm{m}$ below present level, the growth rate of the Morley reef fell to $3.3 \mathrm{~m} / \mathrm{kyr}(R=99$; line 1 in Fig. 7). The growth trend of the Morley reef (Table 1) matches the sea-level history of the Early to Middle Holocene very well for the eastern Australian margin (see Thom and Roy, 1983, 1985), and also shows good agreement with data from the Holocene raised reefs of the Huon Peninsula, Papua New Guinea (Chappell and Polach, 1991; Edwards et al., 1993). This indicates that the Morley reef is a "keep up reef" and therefore a reliable sea-level indicator. In contrast, little variation in growth rate of the reef crest in the Suomi core is observed. The vertical accretion is $6.0 \mathrm{~m} / \mathrm{kyr}$ by $\mathrm{U} / \mathrm{Th}$ age determination $(R=0.99$; line 5 in Fig. 7; Table 1). This, in conjunction with the observation that the rates are higher than the estimated rate of sea-level rise at that time, indicates the Suomi reef is a "catch up reef". The lag of at least 1500 years behind growth of the Morley reef (Fig. 7) further supports this interpretation. 
TABLE 1

Dating results of corals from cores and vertical accretion rates of Morley and Suomi reefs

\begin{tabular}{|c|c|c|c|c|c|c|}
\hline Sample & $\begin{array}{l}\text { DSL } \\
(\mathrm{m})\end{array}$ & $\begin{array}{l}\text { U/Th age } \\
\text { (yr B.P.) }\end{array}$ & $\begin{array}{l}\text { Growth } \\
\text { trend A }\end{array}$ & $\begin{array}{l}{ }^{14} \mathrm{C} \text { age } \\
\text { (yr B.P.) }\end{array}$ & $\begin{array}{l}\text { Growth } \\
\text { trend } \mathbf{B}^{2}\end{array}$ & $\begin{array}{l}\text { Sea-level } \\
\text { rise }^{3}\end{array}$ \\
\hline \multicolumn{7}{|c|}{ Morley reef } \\
\hline $\mathrm{MC}-2 \# 1$ & $+0.3 \pm 0.1$ & $6460 \pm 50$ & $\longrightarrow$ & $5500 \pm 50$ & - & - \\
\hline $\mathrm{MC}-2 \# 2$ & $+0.3 \pm 0.1$ & $6320 \pm 50$ & & & & \\
\hline $\mathrm{MC}-3$ & $-1.3 \pm 0.2$ & $6716 \pm 56$ & $\begin{array}{l}3.3 \\
(\mathrm{~m} / \mathrm{kyr})\end{array}$ & & & $\begin{array}{l}4 \\
(\mathrm{~m} / \mathrm{kyr})\end{array}$ \\
\hline MC-8 & $-2.2 \pm 0.2$ & $7102 \pm 69$ & & $6020 \pm 70$ & $\begin{array}{l}6.5 \\
(\mathrm{~m} / \mathrm{kyr})\end{array}$ & \\
\hline MC-10 & $-5.1 \pm 0.5$ & $7962 \pm 76$ & $\longrightarrow$ & $6355 \pm 55$ & & - \\
\hline MC-12 & $-7.5 \pm 0.1$ & $8124 \pm 44$ & & $6730 \pm 80$ & - & \\
\hline MC-21 & $-11.0 \pm 0.5$ & $8191 \pm 113$ & & $7340 \pm 60$ & & \\
\hline MC-14 & $-14.1 \pm 0.4$ & $8621 \pm 48$ & & $7575 \pm 70$ & & \\
\hline MC-16 & $-17.1 \pm 0.3$ & $9000 \pm 171$ & $\begin{array}{l}10.2 \\
(\mathrm{~m} / \mathrm{kyr})\end{array}$ & & & $\begin{array}{l}10-13 \\
(\mathrm{~m} / \mathrm{kyr})\end{array}$ \\
\hline MC-18 & $-19.8 \pm 0.2$ & $9347 \pm 70$ & & $8145 \pm 60$ & $\begin{array}{l}10.3 \\
(\mathrm{~m} / \mathrm{kyr})\end{array}$ & \\
\hline MC-19 & $-20.7 \pm 0.3$ & & & $7880 \pm 70$ & & \\
\hline MC-4\#1 & $-23.5 \pm 0.2$ & $9610 \pm 50$ & & $8400 \pm 60$ & & \\
\hline MC- $4 \# 2$ & $-23.5 \pm 0.2$ & $9480 \pm 50$ & & & & \\
\hline MC $-4 \# 3$ & $-23.5 \pm 0.2$ & $9484 \pm 77$ & & & & \\
\hline MC-5 & $-25.0 \pm 0.4$ & $9809 \pm 95$ & - & $8470 \pm 60$ & - & $\longrightarrow$ \\
\hline \multicolumn{7}{|c|}{ Suomi reef } \\
\hline & & & & & & $4(\mathrm{~m} / \mathrm{kyr})$ \\
\hline $\mathrm{SC}-4$ & $-6.6 \pm 0.5$ & $5804 \pm 75$ & & $4655 \pm 65$ & & - \\
\hline $\mathrm{SC}-2$ & $-11.2 \pm 0.2$ & $6368 \pm 37$ & $\begin{array}{l}6.0 \\
(\mathrm{~m} / \mathrm{kyr})\end{array}$ & $5575 \pm 55$ & $\begin{array}{l}7.0 \\
(\mathrm{~m} / \mathrm{kyr})\end{array}$ & $\begin{array}{l}10-13 \\
(\mathrm{~m} / \mathrm{kyr})\end{array}$ \\
\hline SC-3 & $-14.2 \pm 0.1$ & $7102 \pm 82$ & 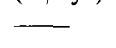 & $5790 \pm 70$ & & $\longrightarrow$ \\
\hline
\end{tabular}

${ }^{1}$ Uncorrected TIMS U-series ages. Reported errors are 2 standard deviations of the mean. ${ }^{2}$ The growth trend (rates) of the reefs are obtained by determining the gradients of regression lines by least square analysis. For details see text. Growth trend $\mathrm{A}$ is from U/Th age determination; growth trend $\mathrm{B}$ from ${ }^{14} \mathrm{C}$ age data. ${ }^{3}$ Sea-level rise rates are based on data from southeast Australia and are from Thom and Chappell (1975) and Thom and Roy (1983).

Variations of accretion rates with time (with stages of growth) observed in the Morley core are consistent with findings on the Great Barrier Reef by Davies and Marshall (1979). These authors found that Holocene reef growth rates changed approximately in the pattern of a sigmoidal curve with a slow rate during earlier colonisation and later when approaching sea level. Davies and Hopley (1983) realised that the sigmoidal curve of growth rate change may be true only when reef growth is controlled mainly by biological processes. Rapid detrital storm deposition may change the growth rate pattern significantly. It seems from our observations that the uppermost part of the sigmoidal curve in reef growth may occur in "keep up reefs", but not in "catch up reefs".

Short-term alkalinity depression measurements in over-flowing waters were used by Smith (1981) to calculate calcification rates of modern coral communities at the Abrolhos. The experiments conducted on a lagoon patch reef in the Easter Group showed no evidence of depressed rates of either inorganic or organic carbon metabolism at the Abrolhos reefs relative to tropical reef communities. The calculated average annual calcification rate was about $12 \mathrm{~kg} \mathrm{CaCO}_{3} \mathrm{~m}^{-2} \mathrm{yr}^{-1}$. Assuming that the reef sediments have an average porosity of $50 \%$ and the coral mound retains all of its 


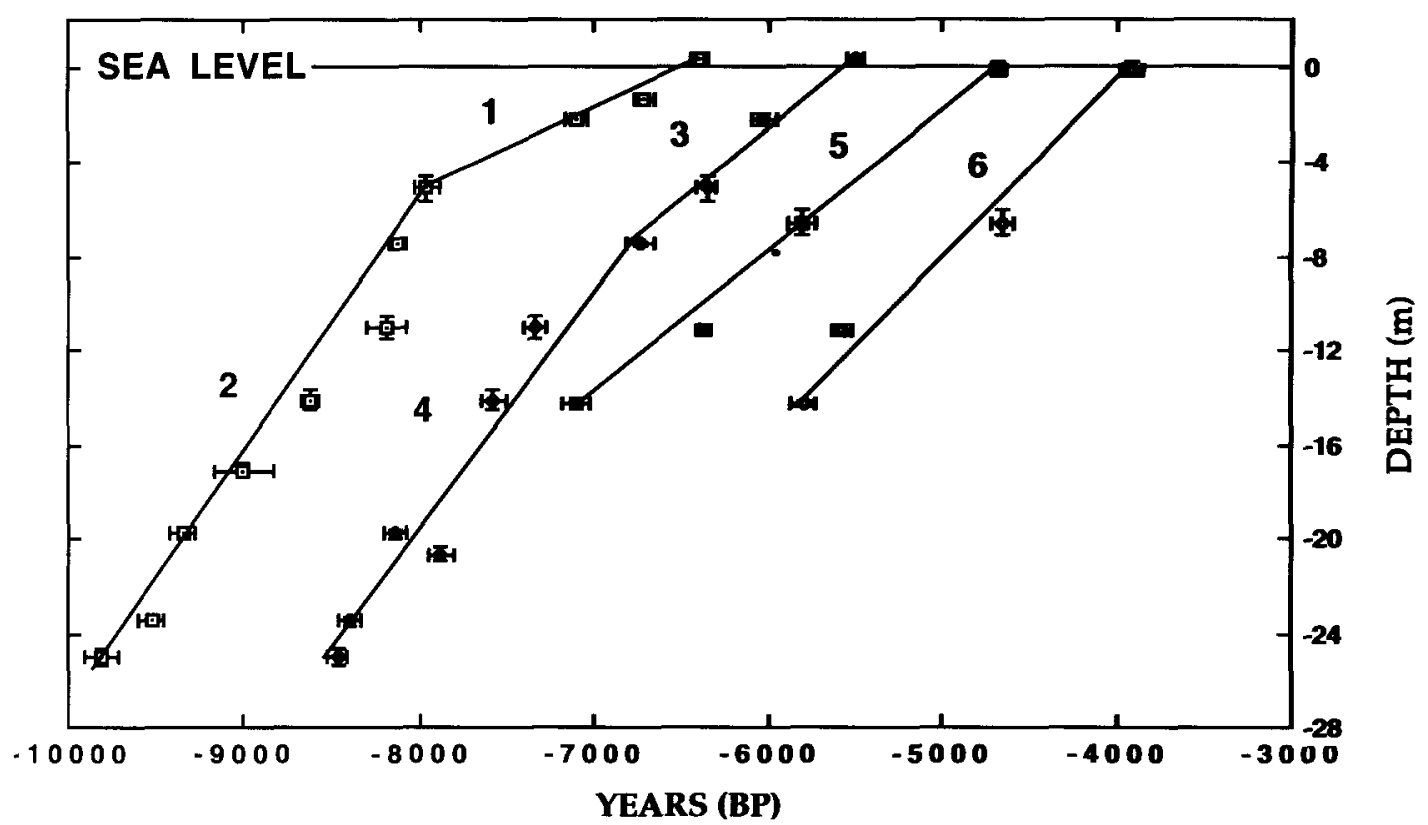

Fig. 7. Growth history of Morley and Suomi reefs in the Holocene, based on dated core material. Note two-stage growth history of Morley core (1-2: U/Th TIMS data; 3-4: AMS ${ }^{14} \mathrm{C}$ data) and uniform growth rate of Suomi core (5: U/Th TIMS data; 6 : AMS ${ }^{14} \mathrm{C}$ data). For discussion see text.

products, the average annual calcification rate is equivalent to vertical accretion rates of $8 \mathrm{~mm} / \mathrm{yr}$ (Smith 1981), which is consistent with the overall vertical accretion rate of $7.7 \mathrm{~m} / \mathrm{kyr}$ for the Morley reef. Kinsey (1985) has noted that protected portions of some Pacific reefs have achieved similarly high $\mathrm{CaCO}_{3}$ production rates. Variations in net community calcification may only partially reflect the pattern of vertical accretion rates obtained by stratigraphic analysis. The core data indicate significantly greater reef accretion took place in the coral-dominated leeward reefs, compared to the coralline algal-dominated windward reefs, in the Early-Middle Holocene (Fig. 5).

\section{Sea levels and reef growth history}

The evolution of the Holocene coral reefs at the Abrolhos is a consequence of the postglacial marine transgression. These reefs provide the most detailed records to date of Holocene sea-level history, both at the Abrolhos, and along the continental margin of Western Australia. Eisenhauer et al. (1993) argue that the growth of Morley reef has kept pace with the Holocene transgression, according to the analysis of the stratigraphy, growth pattern and chronology of the reef and other independent evidence. These authors use the trend of the reef growth, as shown by the growth curve (Fig. 7), as a sea-level record. Because the cored lithofacies represent continuous reef growth, sea level at any time could not have been below this coral reef growth curve, and the curve represents a minimum sea-level curve in the Abrolhos region. The curve thus approximates the sea-level history from approximately 10,000 to $6500 \mathrm{U} / \mathrm{Th}$ yrs B.P. in the region. It indicates that Holocene sea level had reached $-25 \mathrm{~m}$ at ca. 9800 U/Th yrs B.P. From 9800 to 8000 U/Th yrs B.P. there was a generally rapid rise of sea level, with a rate of about $10 \mathrm{~m} / \mathrm{kyr}$. When sea level had reached $5 \mathrm{~m}$ below present level at ca. $8000 \mathrm{U} / \mathrm{Th}$ yrs B.P., the rate of rise decreased to about 3.3 $\mathrm{m} / \mathrm{kyr}$. The sea level at the Abrolhos reached a high of $+0.5 \mathrm{~m}$ above present sea level by 6400 U/Th yrs B.P. From dated reef outcrops we know that the sea level in the region remained at a height of about $+1 \mathrm{~m}$ until at least $4000{ }^{14} \mathrm{C}$ yrs B.P. (Collins et al., 1991). After that relative sea level gradually fell to its present elevation. The Late 
Holocene highstand may have been influenced by hydro-isostatic rebound effects (see Lambeck and Nakada 1990; Eisenhauer et al., 1993). There is no evidence of Late Quaternary tectonism at the Abrolhos.

Lithostratigraphic analysis and radiometric dating of corals from the cores and outcrops reveal the growth history of coral reefs in the Easter Group during the Holocene (Fig. 8). They show that coral reefs in areas with different substrates and energy regimes have different growth histories. The windward parts of the central platforms have a relatively high pre-Holocene substrate, with elevations ranging from $-5 \mathrm{~m}$ to $-9 \mathrm{~m}$ below present sea level. Wave energy in the windward parts of platforms is high because of exposure to strong swells and southwest wind-generated waves. The pre-Holocene substrates on the leeward side of the platforms are relatively lower (greater than -15 $\mathrm{m}$ and $-26 \mathrm{~m}$ at Suomi and Morley Islands). The leeward reef margin experiences relatively lower energy regimes than the exposed, windward reef because the central platform forms a barrier which reduces the impact of swell and wind-generated waves. However, due to swell wave refraction and easterly wind waves, the leeward reefs may also experience moderate to high energy, although less consistently than the windward reefs. The lagoons behind the leeward reef crests have low wave energy and relatively low pre-Holocene substrates.

Corals started to colonise Pleistocene substrates at depths greater than $26 \mathrm{~m}$ below present sea level earlier than 9800 U/Th yrs B.P., probably at the reef crest and definitely in patch reefs in the lagoon adjacent to the leeward reef crests (Fig. 8, I). The exact time of initiation and nature of substrates for the leeward reefs are unknown since the cores did not reach the base of the Holocene reef. Colonization of windward reef substrates did not take place until after $8200 \mathrm{U} / \mathrm{Th}$ yrs B.P., because of the relatively higher elevation ( $-10 \mathrm{~m}$ or less) of Pleistocene substrates.

Details of the timing and pattern of development of the leeward reef and associated "blue-hole" terrains, consisting of coalescent pinnacle reefs, must await further coring and dating. The following discussion is, however, based on the core and chronological data presently available. The growth of some patch reefs (represented by the Morley core), probably as isolated pinnacle reefs on the leeward side of the present-day lagoon, apparently kept pace with the Holocene transgression. The reefs consist predominantly of fastgrowing branching Acropora and grew at accretion rates of up to $10 \mathrm{~m} / \mathrm{kyr}$. However, the reef crest (represented by the Suomi core) seems to have lagged behind sea-level rise. At least 1500 years of lag is suggested by comparing the dating of the Soumi and Morley cores (Fig. 7). The lag of the reef crest behind the transgression may be due to frequent interruptions to coral growth there by destructive storms. These resulted in a slightly slower accretion rate in the Suomi core (average $6.0 \mathrm{~m} / \mathrm{kyr}$ ) compared with patch reef in the Morley core (an average of $7.7 \mathrm{~m} / \mathrm{kyr}$ ). The colonization of windward coral reefs took place when sea level reached about $9 \mathrm{~m}$ below present level and began to bevel the western part of the Last Interglacial platform at this level by intense wave abrasion. The duration of this event and the inevitable lag in reef colonization are unknown, but are assumed to be small. The windward reef grew on Pleistocene substrates with a variety of lithologies, such as eolianite and coralline algal bindstone (Fig. 8, II). Because of the controls of high wave energy and competition with macroalgae, coral growth was not as extensive as in the leeward reefs. Here, slowly developed, are lithofacies of coralline algal bindstone, interbedded with coral framestone.

By $6400 \mathrm{U} / \mathrm{Th}\left(5500{ }^{14} \mathrm{C}\right)$ yrs B.P. when sea level was ca. $0.5 \mathrm{~m}$ above present sea level, some patch reefs in the lagoon, e.g. the Morley reef, had kept pace with sea-level rise and recorded a high sea-level event (Fig. 8, III). However, the leeward reef crest at Suomi Island lagged behind by about 1500 years (Fig. 7). The age of the top of the Soumi core is $4674 \mathrm{U} / \mathrm{Th}\left(3915{ }^{14} \mathrm{C}\right)$ yrs B.P. Outcrops of coral framestones on the leeward reefs show ages not older than $5000{ }^{14} \mathrm{C}$ yrs B.P. The oldest coral shingle storm ridges on leeward reef platforms were formed at about $4800{ }^{14} \mathrm{C}$ yrs B.P. These indicate that now-emergent reef flats on the leeward reefs were formed at about $5000{ }^{14} \mathrm{C}$ yrs B.P. Windward coral reefs lagged far behind sealevel rise. At about $4800 \mathrm{U} / \mathrm{Th}$ yrs B.P., the windward reef at Disappearing Island was still 4 


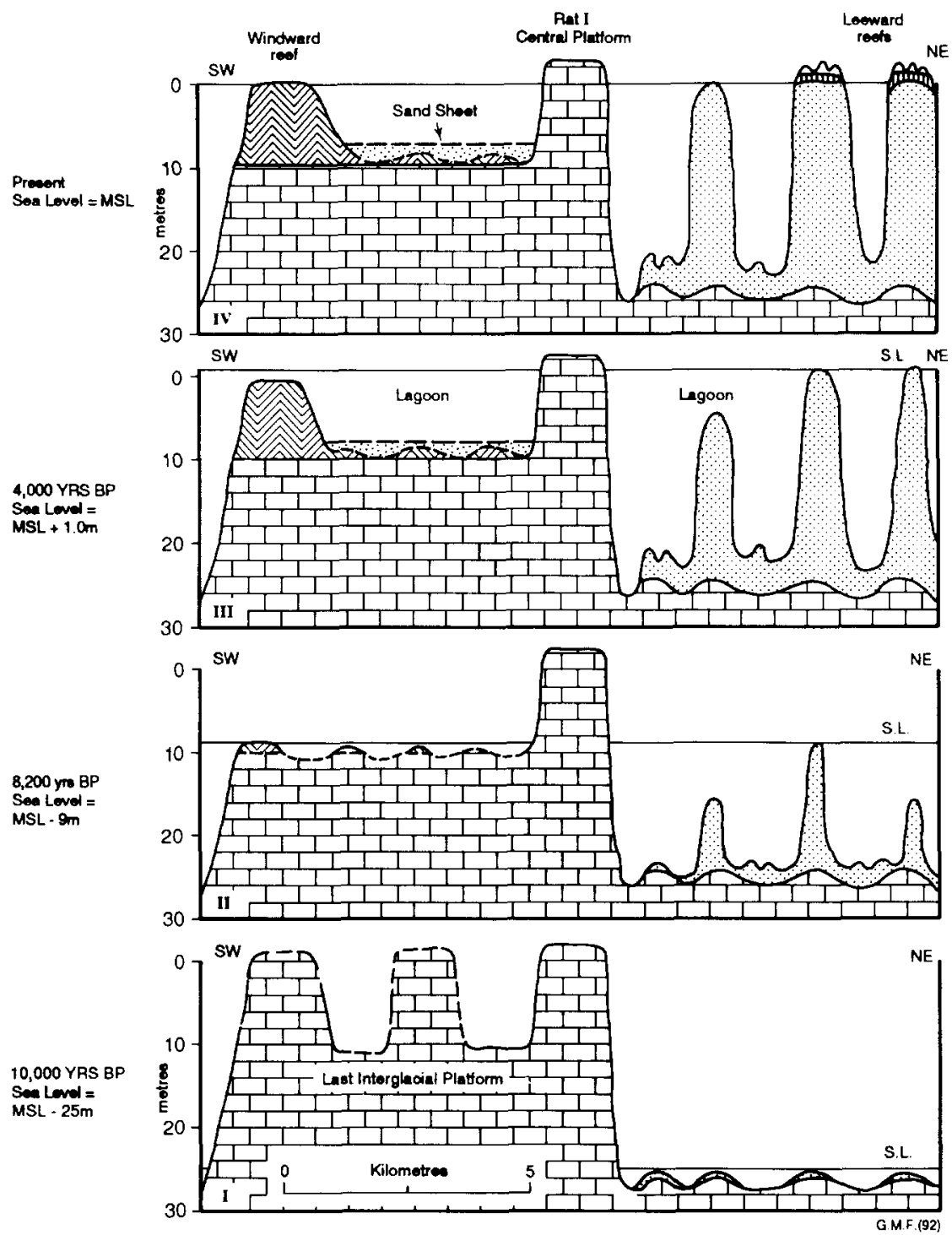

Fig. 8. Schematic cross-section of the Easter Group depicting Holocene evolution. (I) Holocene reef colonization took place on Last Interglacial substrate of unknown lithology in the lee of the Last Interglacial platform. (Note that the morphology of the platform surface is schematic.) (II) Rising seas of the postglacial transgression bevelled the western and central part of the Last Interglacial platform, allowing colonization by the windward reefs (chevron pattern). Leeward reefs (stippled) continued to grow as both "keepup" and "catch-up" reefs. (III) Sea level rose to transgressive peak by 4000 yrs B.P., allowing continued growth of windward and leeward reefs, and development of a lagoon sand sheet sourced by sediment transported leewards from the windward reef crest. (IV) Late Holocene sea-level fall to present MSL produced emergent islands with upward shallowing sequences capped by storm ridges in the leeward reefs. "Blue-hole" terrains were generated by lateral expansion and coalescence of patch reefs in the leeward reefs.

$\mathrm{m}$ below the present sea level. No data are available yet to show when the windward Holocene reef grew to present sea level.

After sea level reached its peak at about 6400 $\mathrm{U} / \mathrm{Th}\left(5500{ }^{14} \mathrm{C}\right) \mathrm{yrs}$ B.P., the rate of change of sea level was very slow. From dated outcrops we know that the sea level in the region remained at a height of about $+1 \mathrm{~m}$ until at least $4000{ }^{14} \mathrm{C}$ yrs B.P. Windward and some leeward reefs started to catch up with sea level and gradually grew to sea level (by about 4500 yrs B.P. in the case of the leeward reefs), eventually forming reef platforms. Leeward coral reefs prograded towards the east. Progradation rates of up to $60 \mathrm{~m} / \mathrm{kyr}$ have been 
calculated for leeward-prograding storm ridges on the platforms. Isolated patch reefs in the lagoon gradually anastomosed, forming extensive, reticulated reef flats having a circular "blue-hole" topography, with depressions $100-1500 \mathrm{~m}$ across and up to $20 \mathrm{~m}$ deep (Figs. 4B and 8 , IV). The "blue holes" are cylindrical to conical in shape and most contain less than $3 \mathrm{~m}$ of carbonate sediments, presumably because of the relatively low supply of sand-sized carbonates in the region. The drilling results indicate that the "blue-hole" terrains in the leeward reefs formed as part of Holocene constructional topography (Wyrwoll et al., in press). Though details of the morphology of the preHolocene substrate are still unknown, the two cores taken on the flanks of "blue-holes" in the leeward reefs (cores 4 and 5; Fig. 5) have demonstrated the presence of $26 \mathrm{~m}$ and $15 \mathrm{~m}$ of Holocene reef growth respectively, without reaching the preHolocene substrate. The thickness of the Holocene buildup ( $>26 \mathrm{~m}$ ) exceeds the usual depth of the "blue-holes", which is $20 \mathrm{~m}$.

\section{Discussion}

The geomorphological work of the 1940s stressed that the atoll-like Abrolhos platforms were dominated by their Pleistocene inheritance (Teichert, 1947; Fairbridge, 1948), citing the significant age of calcretized limestones in platform islands and a widespread karst terrain as evidence. Biological work of the 1980 s and 90 s focused on the transitional biotic characteristics of the reefs and the competition between corals and macroalgae (Wilson and Marsh, 1979; Hatcher, 1985, 1991), growth rates of corals (Crossland, 1981), the absence of healthy corals from windward parts of the Abrolhos reefs (Hatcher, 1991) and the role of the Leeuwin Current in maintenance of the reefs (e.g. Pearce, 1991; Hatcher, 1991). Thus the biological data on the contemporary reefs appeared to reinforce earlier ideas that the Holocene was an unfavourable time for coral growth. All of this work, however, lacked the insights provided by subsurface and chronological data.

The present study shows that the development of the Abrolhos coral reefs in the Holocene, in terms of reef structure and vertical accumulation rates, is comparable with that of tropical reefs throughout the world (Davies and Hopley, 1983; Marshall and Davies, 1984; Davies and Montaggioni, 1985; Macintyre, 1988). This poses questions as to what factors control the development of the Abrolhos coral reefs at a relatively high latitude, and what controls the geological, stratigraphic and sedimentary features of these reefs. This study has found that these controls include the Leeuwin Current, pre-existing topography, and wave energy regimes, modulated by the influence of the postglacial marine transgression.

The persistence of reef growth at the Abrolhos is related to the presence of the warm, southerlyflowing Leeuwin Current which has been well defined by remote sensing techniques (Cresswell and Golding, 1980; Pearce 1991). The Leeuwin Current is formed due to a large alongshore pressure gradient between the warm equatorial waters and the cool Southern Ocean. This meridional gradient induces a net eastwards geostrophic flow from the Indian Ocean towards Australia. The flow is deflected down the pressure gradient by the continent to form the Leeuwin Current. The Current is relatively narrow $(50-200 \mathrm{~km})$ and shallow $(50-200 \mathrm{~m})$. It flows more strongly during the autumn, winter and early spring months than in summer. Peak current speeds can exceed $1.5 \mathrm{~m} / \mathrm{s}$ (Pearce, 1991). The Leeuwin Current is believed to influence many of the factors essential for coral reef accretion, such as temperature, larval delivery and nutrient concentration, and to favour the maintenance of the coral communities (Hatcher 1985, 1991). Though little is known about the behaviour of the Leeuwin Current during the Holocene, it does not appear to have seriously limited coral growth.

While sea-level transgression in the Holocene controlled the timing and rate of reef growth, substrates composed of pre-Holocene (Last Interglacial) reefs affected the onset and distribution of the Holocene reefs. Holocene reef growth was asymmetrical about the Last Interglacial platforms. The shallowly submerged, windward margins of platforms were colonised by coralline algaldominated reefs, presently a few to $9 \mathrm{~m}$ thick, whereas in the leeward reefs, where Last Interglacial reef substrate was poorly developed 
and consequently elevations of pre-Holocene substrates were relatively low, Holocene reefs are well developed, and are over $26 \mathrm{~m}$ thick (see Fig. 8).

The most likely control on the lithostratigraphic differences between the windward and leeward reefs seems to be the different wave energy regimes. The emergent and shallowly submerged central platforms of Last Interglacial reefs form barriers and refract waves, producing two distinct environments on their southwest (windward) and northeast (leeward) sides in terms of wave energy, nutrient concentrations and habitats for coral growth. High wave energy and the abundance of large, canopy-forming algae has resulted in the dominance of coralline algae and slow growth rates of the windward reefs, compared to the fastgrowing coral-dominated leeward reefs. Similar patterns of reef growth have been recorded in the moderate-energy, leeward margin of the Alacran Reef Complex where rapid accumulation of the fragile but fast-growing Acropora cervicornis has built up at least $22 \mathrm{~m}$ thick, Holocene reefs (Macintyre et al., 1977). The effects of energy regimes on growth characteristics of coral reef margins are well documented (Adey, 1978; Davies and Marshall, 1980; Macintyre, 1988).

The present-day expansion of windward-type, coral-poor facies around the southeast margins of the Abrolhos platforms demonstrates the apparent effect of refraction of wind and swell waves approaching predominantly from the southwest. The fast growing branching Acropora species at the Abrolhos are a growth form poorly adapted to high wave energy. Tabulate growth forms are better able to grow (albeit at slower rates) in a wave-swept environment. Species of this form are the dominant coral component of leeward reef and lagoonal patch reefs near sea level, which are exposed to significant fetch. Virtually lacking from the suite of Holocene corals at the Abrolhos are the robust branching, massive and encrusting forms which withstand constant wave shock, and dominate windward coral communities on many tropical reefs (Veron and Marsh, 1988); at the Abrolhos, these are out-completed by soft-bodied macroalgae.

Because they are located at latitudes where conditions for reef development are not as favor- able as those in tropical environments, the Abrolhos reefs have distinctive geological and sedimentary features in comparison to tropical coral reefs. Sedimentary facies analysis shows that although the lagoon sand sheets at the Abrolhos are similar to tropical/subtropical Chlorozoantype skeletal carbonates (Lees and Buller, 1975) and are mainly composed of corals, coralline algae and molluscs, they lack green (Halimeda-type) algae which are significant sediment producers in tropical reefs (Goreau and Goreau, 1973; Scoffin and Tudhope, 1985; Liddell et al., 1989), and also lack non-skeletal grains such as ooids (France, 1985). The reef corals, e.g. Acropora, are relatively poorly calcified (Crossland, 1984). Also, although the accumulation rates of the leeward reefs at the Abrolhos are comparable with those of tropical reefs, the reef facies generally lack sandy sediment and have a high porosity. This reflects a combination of the fast growth of branching Acropora, relatively slow destruction of framework by biological and physical processes and low production rates of sand-size carbonate sediments.

The important characteristics of the Abrolhos reefs are the windward/leeward asymmetry of Holocene reef growth; the contrasting lithofacies and growth rates of the windward (algal bindstonedominated) and leeward (coral framestonedominated) Holocene reefs; the development of "blue-hole" terrain by Holocene reef construction in the leeward reefs; and the lithofacies contrasts between coral-red algal sand sheets on the platforms and the cool-water carbonate sediments on the shelf surrounding the platforms. The influence of the Leeuwin Current on oceanography and coral/algal growth, and the influence of swell wave refraction on sediment transport and reef growth, have been important in modulating reef development throughout the postglacial marine transgression, and may explain the temporal and spatial variation in the relative importance of tropical and temperate elements evident in the stratigraphy. In particular, in the windward reef core, the changes between coral framestone (indicating oceanographic conditions suitable for coral reef growth) and coralline algal bindstone (indicating temperate-cool, high nutrient conditions suitable for macroalgal communities) may indicate changes in 
the strength of the Leeuwin Current and oceanographic conditions, but further data are necessary to test this hypothesis.

\section{Acknowledgements}

Funding for the project was provided by the Australian Research Council. Laboratory work at Caltech was supported by NSF-OCE 9018534 . A. Eisenhauer was partially supported by a fellowship from the Deutsche Forschungsgemeinschaft, EI272/1-1. We are also grateful for the following support: drilling assistance-the Department of Biogeography and Geomorphology, Australian National University; particularly E. Wallenski and D. Kelleher; marine transport-Fisheries Department of Western Australia; particularly R. Owens; coral identification: L.M. Marsh, Museum of Western Australia; drafting-M. Cowin, G. Foster.

\section{References}

Adey, W.H., 1978. Coral reef morphogenesis: a multidimensional model. Science, 202: 831-837.

Bard, E., Hamelin, B., Fairbanks, R.G. and Zindler, A., 1990. Calibration of ${ }^{14} \mathrm{C}$ timescale over the past 30,000 years using mass spectrometric $\mathrm{U}-\mathrm{Th}$ ages from Barbados corals. Nature, 345: 405-410.

Bard, E., Arnold, M., Fairbanks, R.G. and Hamelin, B., 1993. ${ }^{230} \mathrm{Th}-{ }^{234} \mathrm{U}$ and ${ }^{14} \mathrm{C}$ ages obtained by mass spectrometry on corals. Radiocarbon, 35: 191-199.

Chappell, J. and Polach, H.A., 1991. Post-glacial sea-level rise from a coral record at Huon Peninsula, Papua New Guinea. Nature, 349: 147-149.

Chen, J.H., Edwards, R.L. and Wasserburg, G.J., 1986. ${ }^{238}$ U, ${ }^{234} \mathrm{U}$ and ${ }^{232} \mathrm{Th}$ in sea water. Earth Planet. Sci. Lett., 80: $241-251$.

Collins, L.B., 1988. Sediments and history of the Rottnest Shelf, Southwest Australia: a swell-dominated, non-tropical carbonate margin. Sediment. Geol., 60: 15-49.

Collins, L.B., Wyrwoll, K.-H. and France, R.E., 1991. The Abrolhos Carbonate Platforms: geological evolution and Leeuwin Current activity. J. R. Soc. West. Aust., 74: 47-57.

Collins, L.B., Zhu, Z.R., Wyrwoll, K.-H., Hatcher, B.G., Playford, P.E., Chen J.H., Eisenhauer, A. and Wasserburg, G.J., 1993. Late Quaternary facies characteristics and growth history of a high latitude reef complex: the Abrolhos carbonate platforms, eastern Indian Ocean. Mar. Geol., 110: 203-212.

Cresswell, G.R. and Golding, T.J., 1980. Observations of a southward flowing current in the southeast Indian Ocean. Deep-Sea Res., 27: 449-466.
Crossland, C.J., 1981. Seasonal growth of Acropora sf. formosa and Pocillopora damicornis on a high latitude reef (Houtman Abrolhos, Western Australia). Proc. 4th Int. Coral Reef Symp., 1: 663-667.

Crossland, C.J., 1984. Seasonal variations in the rates of calcification and productivity in the coral Acropora formosa on a high-latitude reef. Mar. Biol. Prog. Ser., 15: 135-140.

Crossland, C.J., 1988. Latitudinal comparisons of coral reef structure and function. Proc. 6th Int. Coral Reef Symp., Townsville, Australia, 1: 221-226.

Crossland, C.J., Hatcher, B.G., Atkinson, M.J. and Smith, S.V., 1984. Dissolved nutrients of a high latitude coral reef, Houtman Abrolhos Islands, Western Australia. Mar. Ecol. Prog. Ser., 14: 159-163.

Dana, T.F., 1971. On the reef corals of the world's most northern atoll (Kure, Hawaiian Archipelago). Pac. Sci., 25: $80-87$.

Davies, P.J. and Hopley, D., 1983. Growth fabrics and growth rates of Holocene reefs in the Great Barrier Reef. Bur. Miner. Resour. Aust. J. Geol. Geophys., 8: 237-251.

Davies, P.J. and Marshall, J.F., 1979. Aspects of Holocene reef growth-substrate age and accretion rate. Search, 10: 276-279.

Davies, P.J. and Marshall, J.F., 1980. A model of epicontinental reef growth. Nature, 287: 37-38.

Davies, P.J. and Montaggioni, L., 1985. Reef growth and sea level change: the environment signature. Proc. 5th Int. Coral Reef Symp., 3: 477-515.

Eisenhauer, A., Wasserburg, G.J., Chen, J., Bonani, G.J., Collins, L., Zhu, Z.R. and Wyrwoll, K.-H., 1993. Holocene sea level determination relative to the Australia continent-$\mathrm{U} / \mathrm{Th}$ (TIMS) and ${ }^{14} \mathrm{C}$ (AMS) dating of coral cores from the Abrolhos Islands. Earth Planet. Sci. Lett., I14: $529-547$.

Edwards, R.L., Beck, J.W., Burr, G.S., Donahue, D.J.. Chappell, J.M.A., Bloom., A.L., Druffel, E.R.M. and Taylor, F.W., 1993. A large drop in atmospheric ${ }^{14} \mathrm{C} /{ }^{12} \mathrm{C}$ and reduced melting in the Younger Dryas, documented with ${ }^{230} \mathrm{Th}$ ages of corals. Science, 260: 962-967.

Edwards, R.L., Chen, J.H., Ku, T.-L. and Wasserburg, G.J., 1987. ${ }^{238} \mathrm{U}-{ }^{234} \mathrm{U}-{ }^{230} \mathrm{Th}-{ }^{232} \mathrm{Th}$ systematics and the precise measurement of time over the past 500,000 years. Earth Planet. Sci. Lett., 81: 175-192.

Fairbridge, R.W., 1948. Notes on the geomorphology of the Pelsaert Group of the Houtman's Abrolhos Islands. J. R. Soc. West. Aust., 33: 1-43.

Fairbridge, R.W., 1961. Eustatic changes in sea level. Phys. Chem. Earth, 4: 99-185.

France, R.E., 1985. The Holocene geology of the Pelsaert reef complex, southern Houtman Abrolhos, Western Australia. Ph.D. Thesis, Univ. West. Aust. (Unpubl.).

Garrett, P., Smith, D.L., Wilson, A.O. and Patriquin, D., 1971. Physiography, ecology, and sediments of two Bermuda patch reefs. J. Geol., 79: 647-668.

Goreau, T.F. and Goreau, N.I., 1973. The ecology of Jamaican coral reefs II. Geomorphology, zonation and sedimentary phases. Bull. Mar. Sci., 23: 399--464.

Hatcher, B.G., 1985. Ecological research at the Houtman Abrolhos: High latitude reefs of Western Australia. Proc. 5th Int. Coral Reef Symp., 6: 291-297. 
Hatcher, B.G., 1991. Coral reefs in the Leeuwin Current-an ecological perspective. J. R. Soc. West. Aust., 74: 115-127.

Hatcher, B.G., Kirkman, H. and Wood, W.F., 1987. The growth of the kelp Ecklonia near the northern limit of its range in Western Australia. Mar. Biol., 95: 63-73.

Hawkins, R.D., 1969. Gun Island No. 1 completion report. Bur. Miner. Resour. Aust. Rec., 1968/205 (Unpubl.).

James, N.P. and Von der Borch, C.C., 1991. Carbonate shelf edge off southern Australia: A prograding open-platform margin. Geology, 19: 1005-1008.

Kendrick, G.W., Wyrwoll, K.-H. and Szabo, B.J., 1991. Pliocene-Pleistocene coastal events and history along the western margin of Australia. Quat. Sci. Rev., 10: 419-439.

Kinsey, D.W., 1985. Metabolism, calcification and carbon production I system level studies. Proc. 5th Int. Coral Reef Symp., 4: 505-526.

Kromer, B., Pfleiderer, C., Schlosser, P., Levin, I., Muennich, K.-O., Bonani, G. and Wolfli, W., 1987. AMS ${ }^{14} \mathrm{C}$ measurements of small volume oceanic water samples: experimental procedure and comparison with low level counting technique. Nucl. Inst. Meth., B29: 302-305.

Lambeck, K. and Nakada, M., 1990. Late Pleistocene and Holocene sea-level change along the Australian coast. Palaeogeogr., Palaeoclimatol., Palaeoecol., 89: 143-176.

Lees, A. and Buller, A.T., 1975. Modern temperate-water and warm water shelf carbonate sediments contrasted. Mar. Geol., 13: M67-M73.

Liddell, W.D., Ohlhorst, S.L. and Boss, S.K., 1989. The significance of Halimeda as a space-occupier and sedimentproducer, 1-750 m, North Jamaica. Proc. 6th Int. Coral Reef Symp., Australia, 3: 127-132.

Logan, B.W. (Editor), 1970. Carbonate Sedimentation and Environments, Shark Bay, Western Australia. AAPG Mem., $13,205 \mathrm{pp}$

Macintyre, I.G., 1988. Modern coral reefs of western Atlantic: new geological perspective. AAPG Bull., 72: 1360-1369.

Macintyre, I.G., Burke, R.B. and Stuckenrath, R., 1977. Thickest recorded Holocene reef section, Isla Perez core hole, Alacran Reef, Mexico. Geology, 5: 749-754.

Marshall, J.F. and Davies, P.J., 1984. Facies variation and Holocene reef growth in the southern Great Barrier Reef. In: B.G. Thom (Editor), Coastal Geomorphology in Australia. Academic Press, Australia, pp. 123-134.

Morgan, G.J. and Wells, F.E., 1991. Zoogeographic provices of the Humboldt, Benguela and Leeuwin Current systems. J. R. Soc. West. Aust., 74: 59-69.

Pearce, A.F., 1991. Eastern boundary currents of the southern hemisphere. J. R. Soc. West. Aust., 74: 35-45.

Scoffin, T.P. and Tudhope, A.W., 1985. Sedimentary environments of the central region of the Great Barrier Reef of Australia. Coral Reefs, 4: 81-93.
Smith, S.V., 1981. The Houtman Abrolhos Islands: carbon metobolism of coral reefs at high latitude. Limnol. Oceanogr., 26: 612-621.

Steedman, R.K., 1977. Preliminary study of oceanographic and meteorological conditions as affecting offshore exploration drilling on WA-59-P, Abrolhos Islands area, Western Australia. (Unpubl. Company Rep., Job. No. 053.)

Teichert, C., 1947. Contributions to the geology of the Houtman's Abrolhos, Western Australia. Proc. Linn. Soc. NSW, 71(3/4): 145-196.

Thom, B.G. and Chappell, J., 1975. Holocene sea levels relative to Australia. Search, 6: 90-93.

Thom, B.G. and Roy, P.S., 1983. Sea level change in New South Wales over the past 15,000 years. In: D. Hopley (Editor), Australian Sea Levels in the Last 15,000 Years: A Review. Aust. Rep. for IGCP 61, pp. 64-84

Thom, B.G. and Roy, P.S., 1985. Relative sea levels and coastal sedimentation in southeast Australia in the Holocene. J. Sediment. Petrol., 55: 257-264.

Veeh, H.H. and France, R.E., 1988. Uranium-series ages of corals and coexisting phosphate deposits on Pelsaert Reef Complex, Houtman Abrolhos Islands, Western Australia. Quat. Res., 30: 204-209.

Veevers, J.J., 1974. Western continental margin of Australia. In: C.A. Burke and C.L. Drake (Editors), The Geology of Continental Margins. Springer, New York, pp. 605-615.

Veron, J.E.N., 1974. Southern geographic limits to the distribution of Great Barrier Reef hermatypic odd corals. Proc. 2nd Int. Coral Reef Symp., 1: 465-473.

Veron, J.E.N. and Marsh, L.M., 1988. Hermatypic corals of Western Australia. Records of the Western Australian Museum, Supplement No. 29.

Wilson, B.R., 1977. A preliminary survey of the marine fauna and flora of the Easter and Wallabi groups, Houtman Abrolhos, Western Australia. Records of the Western Australian Museum, Supplement (Unpublished report).

Wilson, B.R. and Marsh, L.M., 1979. Coral reef communities at the Houtman Abrolhos Western Australia in a zone of biogeographic overlap. Proc. Int. Symp. Mar. Biogeogr. Evol. Southern Hemisphere, Auckland, 137: 259-278.

Wolfli, W., 1987. Advances in accelerator mass spectrometry. Nucl. Instr. Meth., B29: 1-29.

Wyrwoll, K.-H., Zhu, Z.R., Collins, L.B., Eisenhauer, A., Hatcher, B.G., Chen, J. and Wasserburg, G.J., 1993. The origin of blue-hole terrain in the Houtman Abrolhos reef complex: western margin of Australia. Geology, submitted.

Zhu, Z.R., Wyrwoll, K.-H., Collins, L.B., Chen, J., Wasserburg, G.J. and Eisenhauer, A., 1993. High precision U-series dating of Last Interglacial events by mass spectrometry: Houtman Abrolhos Islands, Western Australia. Earth Planet. Sci. Lett., 118: 281-293. 